Review Article

\title{
A snapshot of gene therapy in Latin America
}

\author{
Rafael Linden ${ }^{1}$ and Ursula Matte ${ }^{2}$ \\ ${ }^{1}$ Instituto de Biofísica, Universidade Federal do Rio de Janeiro, Rio de Janeiro, RJ, Brazil. \\ ${ }^{2}$ Centro de Terapia Gênica, Hospital de Clínicas de Porto Alegre, Porto Alegre, RS, Brazil.
}

\begin{abstract}
Gene therapy attempts the insertion and expression of exogenous genetic material in cells for therapeutic purposes. Conceived in the 1960s, gene therapy reached its first clinical trial at the end of the 1980s and by December 2013 around 600 genuine open clinical trials of gene therapy were registered at NIH Clinical Trials Database. Here, we summarize the current efforts towards the development of gene therapy in Latin America. Our survey shows that the number of scientists involved in the development of gene therapy and DNA vaccines in Latin America is still very low. Higher levels of investment in this technology are necessary to boost the advancement of innovation and intellectual property in this field in a way that would ease both the social and financial burden of various medical conditions in Latin America.
\end{abstract}

Keywords: gene therapy, gene transfer, gene delivery, viral vector, South America.

\section{Gene Therapy}

Gene therapy attempts the insertion and expression of exogenous genetic material in cells for therapeutic purposes. The transfer of nucleic acids can be performed directly in vivo or through modified cells ex vivo, and it can be combined with other treatments based on conventional medicine, physical therapy, surgical procedures or cell therapies. Interventions in gene expression can be directed toward specific, disease-causing mutations, predisposing factors associated with or circumstantially involved in the pathogenesis of a disease or mechanisms of defense against disease (Friedmann, 1992; Anderson, 1998).

Three major categories may be included in a broad definition of gene therapy: (a) the original idea of direct modulation of the disease-causing gene, which applies to monogenic, hereditary diseases such as hemophilia and a variety of metabolic syndromes; (b) indirect treatment of a disease through gene modulation, which applies to a number of complex, multifactorial acquired diseases in which certain symptoms may be ameliorated by specific intervention, such as Parkinson's disease; (c) immunotherapy by gene modulation (also known as DNA vaccines), in which the classical antigen strategy is either replaced or boosted by the introduction of a gene that directs the synthesis of the relevant antigen or an adjuvant.

Send correspondence to Rafael Linden. Instituto de Biofísica, Universidade Federal do Rio de Janeiro, bloco G, Cidade Universitária, 21941-902 Rio de Janeiro, RJ, Brazil. E-mail: rlinden@ biof.ufrj.br.
Conceived in the 1960s, gene therapy reached its first clinical trial at the end of the 1980s (Anderson, 1998). At the time of this review, a specialized database (http://www.abedia.comwileyindex.html) records a total of 1,970 clinical trials worldwide, of which slightly less than $4 \%$ are in phases III and IV. In December 2013, a debugged search of the NIH Clinical Trials Database using the query [gene therapy OR gene transfer OR virus delivery] returned approximately 600 genuine open clinical trials of gene therapy. Notably, recent advances in recombinant DNA techniques and methods for sequencing the human genome are likely to accelerate progress toward the effective management of both hereditary and acquired diseases through such technologies (Snyder et al., 2010; Campbell et al., 2013; Lisa Li et al., 2014).

This area of research is of interest to the biotech industry because vectors, procedures and therapeutic methods of gene therapy are subject to intellectual property regulations. In parallel with 35,000 academic publications, the field has reportedly accumulated in excess of 16,000 patent applications in the US (Ledley et al., 2014), and a limited number of products have already reached advanced stages of commercial exploitation.

The first biological product for gene therapy strictu sensu (Gendicine ${ }^{\circledR}$ - AdVp53) entered the market in 2003 in China, and three more are in compassionate use in Asia and Europe. In mid-2012, the European Commission authorized the medical use of a gene therapy vector for the genetic disease Lipoprotein Lipase Deficiency $\left(\right.$ Glybera $^{\circledR}$ - 
rAAV-LPL), initially restricted to patients with the most severe form, which is characterized by recurrent pancreatitis. Since 2008, a plasmid encoding the porcine gene for Growth Hormone Releasing Hormone (Life Tide ${ }^{\circledR}$ SW5) that was developed in Australia has provided veterinary gene therapy to increase the number of piglets weaned by sows of breeding age. Due to the growing interest in this field, Global Industry Analysts, Inc. forecasted in 2012 that gene therapy products would represent an 800 million dollar market by 2017.

Following the excitement caused by the first reported successful treatment of severe combined immunodeficiency syndrome caused by a lack of the adenosine deaminase enzyme in the late 1980s (Culver et al., 1991), the field has gone through alternating periods of euphoria and depression. From the beginning, vectors derived from viruses were recognized as the best method for the insertion of nucleic acids, and these are still the most efficient vehicles for the delivery of exogenous genes (except for a few instances in which the target tissues are directly accessible to DNA plasmids) (Verma and Weitzman, 2005). Despite the ongoing efforts to develop other, non-viral vectors and alternative delivery methods (Aied et al., 2013; Amaral and Felipe, 2013; del Pozo-Rodriguez et al., 2013), the alternatives are still relatively inefficient. Although nanostructured compounds may be exempt from some of the perils of viral vectors, significant additional work is necessary to examine both their acute toxicity and other possible adverse effects (Hubbs et al., 2013; Roy et al., 2013).

In certain cases, serious adverse responses have tainted clinical trials, shaken the interest of the biotech industry and undermined public confidence in gene therapy (Check, 2002). However, the rapid pace of basic research offers promising avenues for the development of safer and more effective viral vectors (Huang and Kamihira, 2013; Papayannakos and Daniel, 2013; Petrs-Silva and Linden, 2013), and recent successes have reestablished confidence in this field (Verma, 2013; Wirth et al., 2013). Of course, scientists must proceed with caution, but there is a growing consensus that research, development and applications of gene therapy are due to gain new momentum in the coming years.

\section{Gene therapy in Latin America}

In 2002, an international meeting on gene therapy in Buenos Aires attracted basic scientists and physicians from Argentina, Mexico, Brazil, Chile, Uruguay, Costa Rica, Colombia, Venezuela and Guatemala, with guests from the United States and Europe (Podhajcer et al., 2002). At that time, results from research conducted on this continent were presented by approximately a dozen scientists working in Brazil, Argentina, Chile and Mexico. More recently, in 2011, a Symposium on Gene Therapy in South America was held in Rio de Janeiro, with invited scientists from Brazil, Argentina and Uruguay.

Here, we summarize the current efforts towards the development of gene therapy in Latin America. This analysis is based on reports from the meetings mentioned above, personal communication from faculty at the Annual Latin American School of Human and Medical Genetics (Caxias do Sul, 2005-2013), databases containing information on gene therapy clinical trials, an Internet-based survey (November-December 2013) and PubMed records of publications about gene therapy that contain authors' addresses in Latin American countries.

A search for [gene therapy OR gene transfer OR gene delivery OR "viral vector" OR "non viral” AND Argentina OR Brazil OR Chile OR Colombia OR Mexico OR Paraguay OR Uruguay OR Venezuela] in PubMed returned 329 published papers. Most of these have authors from Brazil (40\%), Argentina (27\%) and Mexico (22\%). The other countries included represent fewer than $10 \%$ of published papers on this subject.

The Internet-based survey retrieved answers from 26 leaders of active gene therapy research groups. Data for seven additional group leaders (GLs), either present at the 2011 symposium or named by scientists in the field, were obtained through PubMed records of articles published by independent research groups in the years 2012-2013. Among the 33 identified GLs, 20 were from Brazil, seven from Argentina, three from Chile, two from Mexico and one from Uruguay.

Among four nonexclusive subfields, most GLs classified their research as directed toward gene therapy (21) and/or vector development (14). In contrast, DNA vaccines were indicated as a goal by 10 investigators, and three GLs also pointed to the development of supplies for therapeutic gene modulation.

All but one of the respondents are working toward the treatment of human diseases, and 4 of them are also interested in veterinary applications. One respondent works specifically on veterinary applications. Among a list of nonexclusive target pathologies, the most frequently reported was cancer, followed by monogenic inherited diseases (Table 1). Several GLs reported the use of more than one type of vector in their research, including stem cells, iPS cells and nanostructured particles (Table 2).

Seventy-five percent of the GLs reported scientific collaborations within Latin America, and one-third reported joint projects with scientists from other countries. All of the respondents are supported by public sources, and only two GLs reported additional private funding. Four locally based biotech companies, three of which are based in Brazil and one in Argentina, were cited as either collaborators or as the commercial source of a clinical-grade vector.

Finally, among the stages of development of therapeutic gene therapy, in vitro development and preclinical 
Table 1 - Target Diseases of Gene Therapy/DNA vaccine research.

\begin{tabular}{lc}
\hline Target disease & Group leaders \\
\hline Cancer & 15 \\
Monogenic inherited diseases & 8 \\
Cardiovascular disorders & 4 \\
Infectious diseases & 5 \\
Neurological diseases & 5 \\
Ocular diseases & 2 \\
Inflammatory diseases & 2 \\
Gene marking & 2 \\
Other* & 7 \\
\hline
\end{tabular}

*Liver diseases, loxoscelism, alcoholism, lung diseases, immunomodulation, Gene-modified implants for cartilage and bone regeneration, Chagas disease and malaria.

Table 2 - Gene transport vectors.

\begin{tabular}{lc}
\hline Vector type & Group leaders \\
\hline Adenoviral & 10 \\
Adeno-associated viral & 7 \\
Retroviral & 8 \\
Lentiviral & 8 \\
Plasmid & 19 \\
Cells (stem ,iPS) & 7 \\
Other* & 7 \\
\hline
\end{tabular}

*Lipopolymeric, nanoparticles, nanoemulsions, Salmonella.

trials were cited by 19 and 24 out of the 33 GLs, respectively. Clinical trials were referred to by seven respondents, of which four are funded by public agencies, and three receive mixed public-private support. To date, results of clinical trials designed and based in Latin America and supported by local funding agencies have been published in a few cases.

In a veterinary clinical trial of a DNA vaccine against bovine anaplasmosis (de Andrade et al., 2004), six seronegative calves were immunized, and their responses to challenge with cryopreserved $A$. marginale were compared with that of five non-immunized control animals. The results indicated that the vaccine provided partial protection against homologous challenge, but a follow-up has yet to be presented.

Results of a phase I human clinical trial of a DNA vaccine containing the mycobacterial hsp 65 gene and directed at head and neck squamous cell carcinoma were also reported (Michaluart et al., 2008; Victora et al., 2009). The vaccine was safe and well tolerated in a cohort of 21 patients with unressectable and recurrent HNSCC, but further studies are required to confirm the initial signs of efficacy recorded in this study.
A clinical trial of therapeutic genetic intervention for canine spontaneous melanoma was also reported. In a large cohort of dogs (a variety of pure and mixed breeds), a combination of a cytokine-enhanced vaccine with thymidine kinase suicide gene therapy showed evidence of long-term safety and efficacy in disease-free overall survival with preserved quality of life (Finocchiaro et al., 2008; Finocchiaro and Glikin, 2008, 2012).

Finally, two clinical trials were reported for advanced ischemic heart disease. Thirteen patients with no-option refractory angina were treated with a plasmid carrying the VEGF 165 gene in a Brazilian phase I/II prospective clinical trial. The treatment was shown to be safe and improve clinical parameters in a follow-up one year later, with a transient increase in myocardial perfusion (Kalil et al., 2010; Giusti et al., 2013). In an independent study in Argentina, 10 patients with no-option coronary arterial disease were also treated with a plasmid carrying the gene for VEGF 165 in an open-label phase I trial with a two year follow-up. This study also observed improved clinical parameters (Favaloro et al., 2013). In both cases, the therapeutic plasmid was manufactured by a national company based in the same country as the trial.

\section{Perspectives}

The chronicle of Science and Technology in Latin America highlights a number of singularities that are now apparent, once again, for a newly developing field. Historically, research funding has been insufficient and has tended to be erratic. Specifically in the health sector, in addition to basic sanitary issues and the increasing costs of both medication and procedures (due to the lack of local innovation and production), advanced treatments may put extra pressure on already constrained budgets. For example, because the Brazilian Constitution guarantees universal access to health care, federal expenses after legal decisions to provide treatments not available within the country are increasing exponentially, and these costs reached 170 million USD in 2012 (http://www.aasp.org.br/aasp/imprensa/clipping/cli_noticia.asp?idnot $=14738$ ). Seventy percent of this amount was used to purchase medications for $661 \mathrm{pa}-$ tients with rare diseases, including Fabry disease, a metabolic disease that is currently a target for the development of gene therapy (Ruiz de Garibay et al., 2013). Gene therapy products and procedures, especially those directed at rare diseases, are likely to be very expensive in the current inaugural period of new technologies, and the expanding offerings expected in the near future are a concern, given the relative lack of Latin American research and development in this field.

For example, to develop Glybera (http://www. bioworld.com/content/first-gene-therapy-glyberafinally-gets-ema-approval-1), the UniQure biotech com- 
pany invested approximately 50 million Euros, and the cost of the treatment is estimated at more than one million Euros per patient. Although such a price seems outlandish, it should be noted that the cost of enzyme replacement for LPL deficiency amounts to a few hundred thousand Euros per patient per year, whereas gene therapy should provide a one-off treatment lasting for many years. Because the number of target patients is a few thousand at most, such high costs are expected, as is also the case for other rare, monogenic hereditary diseases. This has been acknowledged as a problem even by scientists from high-income countries, and novel approaches to reduce the costs of gene replacement are warranted.

Our survey shows that the number of scientists involved in the development of gene therapy and DNA vaccines in Latin America is still very low. Progress in the field may encourage a growing number of doctors to engage some of their patients in multicenter clinical trials. However, approximately $80 \%$ of the currently listed human clinical trials are based in the USA, UK, Switzerland, Germany and France, largely because phase III and IV clinical trials require industrial support to cover the costs of both supplies and logistics.

In conclusion, policy makers should be aware that gene therapy, a novel therapeutic option to cure various diseases, is bound to expand in the near future. However, the current levels of investment in this technology are unlikely to boost the advancement of innovation and intellectual property in this field in a way that would ease both the social and financial burden of various medical conditions in Latin America.

\section{References}

Aied A, Greiser U, Pandit A and Wang W (2013) Polymer gene delivery: Overcoming the obstacles. Drug Discov Today 18:1090-1098.

Amaral AC and Felipe MS (2013) Nanobiotechnology: An efficient approach to drug delivery of unstable biomolecules. Curr Protein Pept Sci 14:588-594.

Anderson WF (1998) Human gene therapy. Nature 392:25-30.

Campbell JM, Hartjes KA, Nelson TJ, Xu X and Ekker SC (2013) New and talented genome engineering toolbox. Circ Res 113:571-587.

Check E (2002). A tragic setback. Nature 420:116-118.

Culver KW, Osborne WR, Miller AD, Fleisher TA, Berger M, Anderson WF and Blaese RM (1991) Correction of ADA deficiency in human $\mathrm{T}$ lymphocytes using retroviralmediated gene transfer. Transplant Proc 23:170-171.

de Andrade GM, Machado RZ, Vidotto MC and Vidotto O (2004) Immunization of bovines using a DNA vaccine (pcDNA3.1/MSP1b) prepared from the Jaboticabal strain of Anaplasma marginale. Ann N Y Acad Sci 1026:257-266.

del Pozo-Rodriguez A, Delgado D, Gascon AR and Solinis MA (2013) Lipid nanoparticles as drug/gene delivery systems to the retina. J Ocul Pharmacol Ther 29:173-188.
Favaloro L, Diez M, Mendiz O, Janavel GV, Valdivieso L, Ratto R, Garelli G, Salmo F, Criscuolo M, Bercovich A, et al. (2013) High-dose plasmid-mediated VEGF gene transfer is safe in patients with severe ischemic heart disease (Genesis-I). A phase I, open-label, two-year follow-up trial. Catheter Cardiovasc Interv 82:899-906.

Finocchiaro LM and Glikin GC (2008) Cytokine-enhanced vaccine and suicide gene therapy as surgery adjuvant treatments for spontaneous canine melanoma. Gene Ther 15:267-276.

Finocchiaro LM and Glikin GC (2012) Cytokine-enhanced vaccine and suicide gene therapy as surgery adjuvant treatments for spontaneous canine melanoma: 9 years of follow-up. Cancer Gene Ther 19:852-861.

Finocchiaro LM, Fiszman GL, Karara AL and Glikin GC (2008) Suicide gene and cytokines combined nonviral gene therapy for spontaneous canine melanoma. Cancer Gene Ther 15:165-172.

Friedmann T (1992) A brief history of gene therapy. Nat Genet 2:93-98

Giusti II, Rodrigues CG, Salles FB, Sant'Anna RT, Eibel B, Han SW, Ludwig E, Grossman G, Prates PR, Sant'Anna JR, et al. (2013) High doses of vascular endothelial growth factor 165 safely, but transiently, improve myocardial perfusion in nooption ischemic disease. Hum Gene Ther Methods 24:298306.

Huang S and Kamihira M (2013) Development of hybrid viral vectors for gene therapy. Biotechnol Adv 31:208-223.

Hubbs AF, Sargent LM, Porter DW, Sager TM, Chen BT, Frazer DG, Castranova V, Sriram K, Nurkiewicz TR, Reynolds SH, et al. (2013) Nanotechnology: toxicologic pathology. Toxicol Pathol 41:395-409.

Kalil RA, Salles FB, Giusti II, Rodrigues CG, Han SW, Sant'Anna RT, Ludwig E, Grossman G, Prates PR, Sant'Anna JR, et al. (2010). VEGF gene therapy for angiogenesis in refractory angina: phase I/II clinical trial. Rev Bras Cir Cardiovasc 25:311-321.

Ledley FD, McNamee LM, Uzdil V and Morgan IW (2014) Why commercialization of gene therapy stalled; examining the life cycles of gene therapy technologies. Gene Ther 21:188194.

Lisa Li H, Nakano T and Hotta A (2014) Genetic correction using engineered nucleases for gene therapy applications. Dev Growth Differ 56:63-77.

Michaluart P, Abdallah KA, Lima FD, Smith R, Moyses RA, Coelho V, Victora GD, Socorro-Silva A, Volsi EC, ZarateBlades CR, et al. (2008) Phase I trial of DNA-hsp65 immunotherapy for advanced squamous cell carcinoma of the head and neck. Cancer Gene Ther 15:676-684.

Papayannakos C and Daniel R (2013) Understanding lentiviral vector chromatin targeting: working to reduce insertional mutagenic potential for gene therapy. Gene Ther 20:581588.

Petrs-Silva H and Linden R (2013) Advances in recombinant adeno-associated viral vectors for gene delivery. Curr Gene Ther 13:335-345.

Podhajcer O, Pitossi F and Agilar-Cordova E (2002) Gene therapy coming of age in Latin America. Mol Ther 6:153-154.

Roy R, Kumar S, Tripathi A, Das M and Dwivedi PD (2013) Interactive threats of nanoparticles to the biological system. Immunol Lett 158:79-87. 
Ruiz de Garibay AP, Solinis MA and Rodriguez-Gascon A (2013) Gene therapy for Fabry disease: A review of the literature. BioDrugs 27:237-246.

Snyder M, Du J and Gerstein M (2010) Personal genome sequencing: Current approaches and challenges. Genes Dev 24:423-431.

Verma IM (2013) Medicine. Gene therapy that works. Science 341:853-855.

Verma IM and Weitzman MD (2005) Gene therapy: Twenty-first century medicine. Annu Rev Biochem 74:711-738.
Victora GD, Socorro-Silva A, Volsi EC, Abdallah K, Lima FD, Smith RB, Moyses RA, Zarate-Blades CR, Michaluart P, Silva CL, et al. (2009) Immune response to vaccination with DNA-Hsp65 in a phase I clinical trial with head and neck cancer patients. Cancer Gene Ther 16:598-608.

Wirth T, Parker N and Yla-Herttuala S (2013) History of gene therapy. Gene 525:162-169.

License information: This is an open-access article distributed under the terms of the Creative Commons Attribution License, which permits unrestricted use, distribution, and reproduction in any medium, provided the original work is properly cited. 